\title{
Training and Practice of Occupationals Who Work with Children Aged from Zero to Two in Institutions of Childhood Education
}

\author{
Fabiana Cristina Frigieri de Vitta1,2, Maria de Fátima Carneiro Ribeiro Pereira ${ }^{3}$, \\ Beatriz Aparecida Barboza do Nascimento², Bárbara Solana Scarlassara², \\ Claudia Regina Mosca Giroto ${ }^{1,2,4}$, Alberto de Vitta ${ }^{5}$ \\ ${ }^{1}$ Department of Especial Education in the Faculty of Philosophy and Sciences (FFC), UNESP, Marília, Brazil \\ ${ }^{2}$ Postgraduate Program on School Education in the Faculty of Science and Letters (FCLAR), UNESP, Araraquara, \\ Brazil \\ ${ }^{3}$ Faculty of Psychology and Educational Sciences, University of Porto, Porto, Portugal \\ ${ }^{4}$ Postgraduate Program on Education in the Faculty of Philosophy and Sciences (FFC), UNESP, Marília, Brazil \\ ${ }^{5}$ Program of Postgraduate on Physiotherapy in the Universidade Sagrado Coração (USC), Bauru, Brazil \\ Email: fabianavitta@gmail.com,fpereira@fpce.up.pt, beatrizbnasc@gmail.com, \\ badomettsolana@hotmail.com,claudia.mosca@marilia.unesp.br, albvitta@gmail.com
}

Received 5 May 2016; accepted 11 July 2016; published 15 July 2016

Copyright (C) 2016 by authors and Scientific Research Publishing Inc.

This work is licensed under the Creative Commons Attribution International License (CC BY).

http://creativecommons.org/licenses/by/4.0/

(c) (i) Open Access

\section{Abstract}

The education of the children aged up to 2 years old is a current and necessary concern on childhood education. There are only a few studies in the area and the official documents do not satisfactorily contemplate this age group. This paper presents results of a research developed between 2011 and 2013, with the objective of understanding the effects of continuing education practices on the qualification of occupationals who work with children aged up to 2 years old, in institutions of childhood education of an average-sized city in the State of Sao Paulo, Brazil. In order to do so, we performed four assessment procedures (initial, intermediate, final and after six months) which included the individual communications (questionnaires and interviews) and participant observations of everyday practice in the nurseries. We applied two educational procedures in-between the assessments-educational workshops and practice monitoring. The contents of results were analyzed for the comparison of data from the different stages. This paper presented the results from the opinions of 50 participants regarding the procedures developed for the training-workshop and practice monitoring-discussed in two themes: background knowledge and practices; and the training of nursery occupational. The analysis highlighted the need for the implementa- 
tion of initial training on the specific reality and the continuing monitoring in service, according to the occupational practice and the nursery situation.

\section{Keywords}

Childhood Education, Babies, Occupational Training, Continuing Education, Nursery

\section{The Education of Young Children in Brazil}

Kramer (2006) and Rosemberg (2011) emphasize that the education of children of 0 to 3 years old is quite neglected in Brazilian public policies and there is urgency of studies about daycare and work with babies, searching discussions of incorporation on rights and duties in relation to this age group.

Nörnberg (2013) points out that

Not always the proposals that are being implemented are characterized by a set of articulated policies that, in fact, promote suitable conditions, in relation to the physical, material, and especially to humans, especially those that focus directly on the formation of the person, whose actions they are aimed at provision of basic needs of the children (p. 104).

The UNESCO report (Organização Para A Cooperação E O Desenvolvimento Econômico, 2002) about early childhood, education and care (ECPI) shows, through the analyses presented, that in most countries, the policy in favor of children under the age of three years old also includes the idea of child protection, similar to Brasil.

However, as highlighted by Vitta, Giroto, De Castro, Campanhã, De Souza, Solana, Novaes, Cicilino, \& Vitta (2015: p. 520),

The organization's activities routine, taking into account the child's learning and development needs, is an important gap between the school and the family. In other words, the activities and the considered care or education should be structured to promote the child's skills, and by its purpose and planning, to differentiate those made at home by the family.

Those difficulties relative to organization of childhood education at the nursery they are reflected in the training of occupationals to work in early childhood education with children aged 0 to 3 years old (Campos, Füllgraf, \& Wiggers, 2006; Kramer, 2006).

We must consider that all these discussions promoted to help in the organization of a quality school for the care of children from 0 to 3 years old refer to the understanding of contexts of interest by those who produce those materials and the occupational training to act in these institutions. Pereira (2009: p. 93) discusses about the childhood government and the teaching occupation and points out that these are influenced by "individual rationality and justice systems". In other words, the way how understand the little child influences the production of knowledge and structuring the training offered to the occupationals who will work with this child.

Campos, Füllgraf, \& Wiggers (2006) conducted a study about the production of knowledge in early childhood education area produced between 1996 and 2003, and they found that a few studies about the practice of teachers and educators in early childhood education institutions were carried out. In relation to studies about children aged 0 to 3 years old, they observed a "lack of clarity of the teachers about their role, which leads them to confuse the responsibilities of childcare and family, not distinguishing between the public and private space" (p. 104). The references to practice at this age are found in family, used as a model, especially among occupationals who assist teachers in child care.

Campos, Füllgraf, \& Wiggers (2006) and Kramer (2006) point out that this is one of the challenges for the performance of educational policies.

Training teachers to deal with small children is a new task in Brazilian school history and for many, unknown and even less noble, having children less than 7 years old in school seems to surprise or impact on managers and researchers (Kramer, 2006: p.804).

Oliveira (2001) and de Vitta \& Emmel (2004) consider that the appreciation of the occupational role is crucial to improving the quality of early childhood education and that value goes through initial and continuing training of quality that allow the construction of their knowledge through critical access to educational proposals for the area. Those data are confirmed by Campos, Esposito, Bhering, Gimenes, \& Abucham (2011) e Campos, Bhering, 
Esposito, Gimenes, Valle, \& Unbehaum (2011).

When one talks about continuing education, it must consider its direct relation to the changes and demands from current society, always aiming the need for occupational updating and renewal. This speech is very pronounced in developed countries in all occupational and college sectors, highlighting how essential is this continuing education thanks to changes in knowledge, technology and the labor market.

The idea of continuing education in exercise, based on the practice of occupational activities performed routinely, may favor a quality performance that respects and consider the particular needs of nursery children, as well as the specific characteristics of this level of education. Oliveira (2001) shows that continuing education provides "a constant reflection on their beliefs and values, as well as their educational practice that emerges from the various theoretical approaches to the child development and education” (p. 95). There is need of continuing education organization, helping the occupational improve their knowledge level, but which provides the practice of it. It is necessary that this training happens during routine nursery, so that the practice can be incorporated gradually and within the possibilities. Volpato \& Mello (2005), on discussing the work and training of childcare occupationals in Botucatu, highlight the need to initial and continued theoretical and practical training, considering aspects of reality. Focus in the importance of deepening the knowledge on part of the leaders, including managers, supervisors and municipal government, as there is a network of institutional relationships and interests that guide the educational project of nursery, presuppositions also defended by Santos (2005).

Neves (2013), in a survey in which uses memories and educators narratives and founders of a community nursery on the outskirts of Belo Horizonte, shows the existing identification of the life stories of occupationals who serve the institution and the children involved and to interfere in the relationship and design of their work. Alert to the need to pay attention in occupationals of educational field training, for "the reconstruction of teachers' life stories by themselves and also for the institution” (p. 243). Consider this aspect may be a difference in the organization of the relationship between the beliefs of the occupationals and their action with children, moving from a paternalistic pedagogy to another that promotes to the child and their possibilities of appropriation and construction culture.

That way, there is need of commitment among the entire team that works in the institution, including directors, management assistants, service assistants, because the change in routine requires support in all areas. Paniagua \& Palacios (2005: p. 241) points out

The teachers' training is particularly valuable when it is done with the whole team and the commitment to reverse to the educational action. It's very common that the training and the reality of classes advances in different ways. Professionals accumulate courses to enjoy them as an intellectual exercise, but rarely force themselves to modify their activity consistent with what they had learned. When this training is individual, our own resistance to change adds to the difficulty in transmitting what has been learned to the team. Therefore, training opportunities for team-always costly, not only economically but also in organization of time and collective effort-must imply a strong commitment to implement at least the most consensual and significant conclusions.

Campos, Esposito, Bhering, Gimenes, \& Abucham (2011) e Campos, Bhering, Esposito, Gimenes, Valle, \& Unbehaum (2011) reinforce the need for greater attention to this stage of basic education and shows several aspects that must be considered to improve the quality, among them the need for continued training of personnel and team.

Besides, Kagan (2011) on make a critic to quality of Brazilian early childhood education, specifically, but referring to the same problems in other countries, emphasizes the need to create a "childhood education system" in which "several elements work together to produce high programs quality” (p. 64), which are connected to the direct service programs with the child and family and an infrastructure to support them, among which we highlight the occupational training that includes the teams.

To Early Childhood Education occupationals who are already in the labor market, it is necessary to think about a training that includes knowledge related to specific content related to child development and ways of support it, but also allow discussion of practical aspects already found in the services performed. According to Vitta \& Vitta (2012), the knowledge that the nursery occupationals have on child development processes in the child's social context is one of the factors that determine the quality of work.

This article presents results of a research conducted between the years 2011 and 2013 with the objective of understand the effects of continuing training practices in the qualification of occupationals who are in service with the children from 0 to 2 years old inserted in early childhood education institutions in a medium city size of the State of Sao Paulo-Brazil. 


\section{Methodological Approach}

The participants of this research were 50 employees of four nurseries of a medium-sized city in the state of Sao Paulo, 2 of them were directors, 3 auxiliary direction, 10 teachers, 18 development school assistants (ADE) and 17 general services auxiliary (ASG). Regarding to the profile of the participants, which can be seen in Table 1, it was observed that most participants were aged between 40 and 49 years. It was found that only the teachers, management assistants and directors had higher level of training, predominantly training in high school not directed to the teaching function between ADE and ASG. Some ADE were doing a degree in pedagogy. Most occupationals were in childhood education and nursery for more than two years and used knowledge coming from their practice and personal experience to work with this age group.

The delineation operational procedures counted on four stages. The initial assessment, which was engaged in the routine activities proposed in the nursery and its use as a resource for child development such as in the daily life of educational institutions. It included individual communications (questionnaires and interviews) and observations of behavior and customs relating to activities (participant observation). Such instruments considered the objective research, the bibliographic reference of the area and the research conducted by de Vitta \& Emmel (2004), with open questions to allow the participants to think of their activities and organization their knowledge about their thoughts and practices in everyday nursery.

The topics of interest, dealt with in the questionnaires related to the care (organization of the materials and the children for the activity), content/objectives (for which the activity is performed and which contributes), materials (appropriateness of the materials used) space (adequacy of used space), instructions (given to children for the activity realization), participation of children (how that happens) and the possible changes that they judged necessary. The interviews focused concepts related to the role of nurseries and evaluation of educational procedures applied as described below.

Then, two educational programs were applied with the occupational aiming to analyze and discuss the nursery

Table 1. Distribution of absolute and relative frequencies of the participants' profile.

\begin{tabular}{|c|c|c|c|c|c|}
\hline \multirow{2}{*}{\multicolumn{2}{|c|}{ Categories }} & \multicolumn{2}{|c|}{ Teachers, direction e auxiliary direction } & \multicolumn{2}{|c|}{ ADE/ASG } \\
\hline & & $\mathrm{N}$ & $\%$ & $\mathrm{~N}$ & $\%$ \\
\hline \multirow{5}{*}{ Age groups } & $20-29$ & 0 & 0 & 2 & 5.7 \\
\hline & $30-39$ & 3 & 20 & 11 & 31.4 \\
\hline & $40-49$ & 9 & 60 & 17 & 48.5 \\
\hline & $50-59$ & 3 & 20 & 3 & 8.5 \\
\hline & 60 or more & 0 & 0 & 2 & 5.7 \\
\hline \multirow{5}{*}{ Training school } & Elementary and middle school & 0 & 0 & 2 & 5.7 \\
\hline & High school & 0 & 0 & 22 & 62.8 \\
\hline & Technical course in teaching & 0 & 0 & 3 & 8.5 \\
\hline & Incomplete higher education & 0 & 0 & 4 & 11.4 \\
\hline & Complete higher education & 15 & 100 & 4 & 11.4 \\
\hline \multirow{4}{*}{ Years in childhood education } & Less than a year & 0 & 0 & 8 & 22.8 \\
\hline & 1 to 2 years & 0 & 0 & 4 & 11.4 \\
\hline & 2 to 5 years & 1 & 6.6 & 5 & 14.3 \\
\hline & More than 5 years & 14 & 93.3 & 18 & 51.4 \\
\hline \multirow{4}{*}{ Years in nursery } & Less than 1 year & 4 & 26.6 & 11 & 31.4 \\
\hline & 1 to 2 years & 1 & 6.6 & 3 & 8.5 \\
\hline & 2 to 5 years & 5 & 33.3 & 7 & 20 \\
\hline & More than 5 years & 5 & 33.3 & 14 & 40 \\
\hline
\end{tabular}

Source: Research data. 
activities routine, seeking to improve their theoretical and practical knowledge. It consists of an educational workshop with 45 minutes duration, taught in 4 consecutive weeks at the end of a work day, at the nursery. This workshop comprised technical demonstrations, practical applications and feedback, which added the "how to do" and helped in the development of activities to stimulate the development of the child 0 to 2 years old. The topics approached the child's motor skills development from 0 to 2 years old and the effects of hygiene activities, clothing and food for the stimulation in this age group. In the meetings, were emphasized the relationship between care practices and the child's learning, with focus on motor, due to postural changes and child handling. Nursery own utensils were used what allowed to discuss the difficulties of occupationals and possible solutions.

The second educational procedure used consisted of supervised practice, which occurred during the routine of occupational activities, with 15 hours of total duration. In all activities focused postural changes and the necessity of intentionality in the child's manipulation.

Intermediate and final reevaluations were performed following the same initial assessment procedure. The intermediate was made one week after the completion of education workshop and the final was done after a week of supervised practice end. Finally, the theoretical and practical knowledge of the concepts and routine activities were reevaluated after six months of the end of educational interventions, following the same initial assessment procedure.

The data obtained in the three instruments of collect, together, provides an insight into theoretical and practical knowledge relative to the concepts and routine activities of each research participant. They were organized and classified according to Minayo (2000), what allowed the confrontation between the results obtained in different stages of evaluation, checking the conceptual and practices changes related to activities in the nursery routine. The study was submitted to the Ethics Committee of the FFC-UNESP-and approved under the number 0010/2000.

For this manuscript, interests focus on the responses of the participants, by evaluating the teaching procedures, through open questions inserted in the interviews that took place at the end of education workshop and supervised practice. In those moments, the subjects were also asked to list possible changes caused by the training offered. In the last interview, six months after the end of the procedures, they were asked about the best way to provide and organize a training that attended your needs. The considered occupational speech, relevant to illustrate the results, is highlighted in italics, appearing in parentheses their role and the institution they belong to.

In order to systematize how participants evaluated the procedures of training offered, two contents appear in the speeches and worth mentioning: 1) occupationals conceptions about children and nursery and its influence on practice performed during the daily routine; and 2) the relationship between initial and continuing education, which influences the known content and the required content.

\section{Previous Knowledge and Practices}

The interventions evaluation, it was observed that the participants recognize the importance of having access to new job opportunities, and many reported that the knowledge obtained in the theoretical classes were reinforced in practical supervision. While highlighting that the application of the theory was difficult, mainly because of the physical infrastructure and equipment and the nursery established routine, they reported having greater awareness of the actions they perform and their relationship with the child's development.

Certainly, the posture change issues, we think the nursery baby, do you think the child does not have much to do, but just the fact that you take her from the comfort baby, let them sitting, help them sit all this is very important, that's what helped ( $A D E, B C)$.

Although many lines recognize that there is need to look at the child as a active human being, social, when the occupationals say that the infrastructure hinders, clearly faced up in the conceptions related to child and their care particular of this age, they must be privileged.

The difficulty in understanding the children's education, especially in the period corresponding to the age from 0 to 2 years old is big in Brazil and the care of babies is still precarious, regarding to the supply and the quality (Rosemberg, 2011; Campos, Esposito, Bhering, Gimenes, \& Abucham, 2011; Correa, 2011). This fact relates to the woman conceptions and children, their rights and duties. Some studies deal with those issues properly (Dias, Pereira, \& Correia, 2014; Cerisara, 2002).

...put the question that here is not a hospital, it's a place to educate, to learn, when was taught us how we must carry the time to give meals to the children sitting, ah, there I found the maximum, there I've learned, there 
I started to learn that we can change ( $A D E, B A)$.

I think it was very good. I had never worked with nursery, was very helpful, I learned a lot. (...) The idea I had was the mother. I worked in a kindergarten. The notion that I had of my son, and now I see another school thing, more professional, it is not only caring for the mother can go to work (ASG, BD).

The idea that permeates the work with the nursery children is completely influenced by concepts built in day to day personal and professional of teachers and assistants, influencing directly in their work. What is observed it is a great correspondence between the idea of welfarism and vocation, supported the role of women in society. In analyzing the similar institutions of care for children from 0 to 2 years in Portugal, Dias Correia \& Pereira (2013) emphasize that the service, as it has been organized "reveals the lack of a pedagogical tradition of support, ideological prejudices that they are intrinsic, insecurity and inferiority present in nursery" (p. 668).

In relation to the knowledge of teachers and studies developed for analysis, Tardif reports that there is a plurality of views. Points out that

it is very difficult to isolate the question of knowledge of teachers of other dimensions of teaching: training, professional development, identity, career, working conditions, tensions and socio-educational problems that mark the profession, characteristics of educational institutions where teachers work, content school programs, among other dimensions (2013, p. 567).

Oliveira, Silva, Cardoso, \& Augusto (2006) share this view and point out that the teacher has your professional and personal development complexly organized, often by contradictory situations and aspects, originated in social institutions, by the scientific research, laws, etc.

Furthermore, in relation to the occupationals beliefs about their work and the public they serve, Pereira (2009) talks about the heterogeneity produced when comparing the institutional discourses and teachers (who end up having a practice controlled by contingencies of contexts and situations acting). That is, the pedagogical speech, widely used in initial training end up empty-when confronted with the reality of institutions. The speeches of the participants of this study confirm this statement because they punctuate the difference between what one wants and what one can do in day to day operations.

.... a lot of things that she spoke on the course and even her talking like that, open, a little, our head, but in practice it is difficult for us to do and change, even knowing that it is right, but because of this, the run, the lack of employee $(A D E, B B)$.

Obviously, this 'want' and that 'power' are strongly influenced by their conceptions, a fact that also interferes when analyzing the Brazilian production of this period of education, represented by the lack of bibliographic material which reports that (Campos, Fullgraf, \& Wiggers, 2006).

What is observed today in various institutions that serve the little child is very similar to the description given by Tardif (2013) of the teacher occupation as a vocation, or is on a mission, including related to religion. Although this idea goes back to the sixteenth and eighteenth centuries, it finds many similarities. According to Tardif (2013) the main function of the teacher was moralizing children and not teaching them. "The teaching at the age of vocation was therefore essentially a moral work consisting of deeply acting in the souls of children, discipline it, guide it, monitor it, control it” (p. 555). In this line of thought, the occupation was undervalued, often done without payment.

The training was almost non-existent: the religious and lay women learned to teach in loco, the experience and imitating the most experienced teachers. The "traditional feminine virtues" were valued and served as justification for the lack of training: love for children, obedience, devotion, spirit of sacrifice, spirit of service... (Tardif, 2013: p. 555).

In Brazil observed a similar reality. While one cannot speak directly to religion in municipal institutions, maternity idea in understanding the practice prevails, as well as a deficit formation of many of the occupationals who are municipal servent for different technical positions (development aids, school attendants and others) placed to help in the nursery rooms to help the teacher, learning from older services, which is not always the teacher.

The nursery is better than home in this way, because the experience of the teacher, dealing with education, they already have training. We are a mother without training. One is mother because fate decreed. We became pregnant, had the babies, learns from mistakes, but the teacher did not, is an expert, right, which is to spend an experience because she studied for it, I think it is important (interview. \#1, ASG, BD).

I think we have a little progress, very little...The courses that we have, I've had that job for 14 years already, so a little bit you get, because in theory is everything beautiful, all that talk on theory, do this, do that with the 
child is beautiful, only the time you put in a public nursery, in practice it is totally opposite what we learned. So I think there should be more practical, more people in, evaluating the school content, evaluating the space (...) (ADE, BA).

In this context, there is the need to review pedagogical practice as a whole in childhood education schools, especially those who attend the nursery, by organizing educational projects that aim to respect and development of children in this age group. Therefore, it is important to think in the formation of occupationals who work in these institutions, with the child.

\section{Training for Occupational Nurseries}

Although the research has achieved results in practice, the picture showing the child's education from 0 to 2 years old is compounded by lack of university initial training that deals with the nursery theme in an appropriate way, focused on the care needed for this age group, reinforcing the link to a "vocational" care teacher, as already noted.

First, with the smaller children, life in classes is a succession of activities in which intercalating the needs of everyday life-cleanliness, food, etc. With moments of play-exploitation, music, interactive game, game engine. All are natural educational activities and close to the children, and there is no reason to invent others. Of course, keep clean and fed children, and then let them play to their heart's content the rest of the time is not synonymous with educational intervention; for this happen, both the moments of personal care as a playtime should be stimulating (Paniagua \& Palacios, 2005: p.174).

...[Practice supervision] changed my way of thinking. (...) Because at first I thought it was mostly the same as to take care, but after her course I've seen that is of great importance in learning (teacher, BB).

Arce (2010) makes a critique of a certain spontaneity defended by the National Curriculum Reference for Early Childhood Education, which distance the school of early childhood education, ignoring the teaching that must be present as a focus of pedagogical action, that means, these institutions shall be considered the place "privileged knowledge systematized" (p. 31), without ignoring the daily. Points out, when dealing with early childhood education (although emphasizes age $4-6$ years old), the importance of the teacher's training and conduct. When the early childhood institution has a commitment to teaching, there is a "teacher's rescue as an intellectual who must have a solid theoretical and practical knowledge, will not be enough just to like children, the teacher here is someone who must have broad cultural capital” (Arce, 2010: p.32).

Another point that Tardif (ibid.) points out is that the occupation as a vocation is directly linked to hierarchy and external control, a fact clearly seen in the institutions that attend little child in Brazil. In nurseries, you see the external control dictated by political ideologies-in public institutions-which while guaranteeing the right to education advocated by the laws, organizing routines and activities based on the concepts and specific contexts of those who drive at the municipal level and politicos' interests. Still, submits to the power of parents (since the children are small and dependent) who, in private institutions, for pay and be directly responsible for the livelihood of the institution, regulate the activities that are carried out according to their interest and culture. The philanthropic institutions, religious ideologies mainly determine its operation.

Even today, the moral dimension (or rules) is still very present (...) the working conditions of teachers are sometimes hard and they are not valued socially, which occurs in most countries in Latin America and Brazil. In summary, even being old age of the calling still showed, in part, around the world, the work of teachers and their status (p. 556).

The teacher profession, says the author, is being implemented slowly, including in Brazil. However, it is a mistake to think does it happen at all levels, it is clear there is difference appreciation of teachers in different stages of education, and the care nursery still runs the school of understanding, getting relegated to the child's views, mother, education and care of the actors responsible for the institutions-Municipal education Department, directing, teaching coordination (when existent) and teachers and attendants, all theoretically governed by higher laws created by the Ministry of education. It is said to be governed by widely reported that responsibility for this phase of education was transferred to the municipal, causing it to investigate different cities, you see different forms of assistance to the little child.

In fact, Brazil has directed education for children from 0 to 2 years old as a way to solve social problems and risks installed over many years in which the policies were inefficient to produce equity. However it is necessary that the care to this child to be a social right, leaving the welfare dimension, designed to solve major structural 
social problems (Campos, 2013; Arce, 2010).

Professionals who are in day care centers should be conscious that the activities that offer actively contribute to the child's overall development and belong to two categories-care and education. Bahia, Magellan, \& Bridges (2011) highlight the relationship between the understanding of work on the development of the child and their actions as educators, the most common activities for the care of small children. Arce (2010) complements these ideas, pointing out that each activity to be developed with the child, even though the care's one, has to be intentional, planned and organized to teach it according to the phase in which the child is.

Thus, associate educational programs that combine theory and practice are absolutely relevant. The participants in this study reported how the practice supervision was important for the theoretical knowledge make sense in the nursery routine.

I think the girls even take care of, how they are caring, the way they are changing, giving food, really seeing how the child sits, be able to help the child to be developing better. So in the course she could...we are focusing more on that aspect (director auxiliar, BB).

....all the activities that I was developing I also tried to take another look a, t everything here that she put me in, feeding time, activities time that are carried out on the table, the time I'm going to get a child, the time I'll get up in time I'll hold, time to eat, how to play, in the way of teaching to play, we have another look at what she taught for us, it was excellent (teacher, BA).

You must understand that this age group has specific characteristics that should be considered. Obviously, a baby needs hygiene, food and clothing, but these practices cannot avoid a pedagogical responsibility.

As highlighted by Gatti (2013), "practices generate theories and theorizing generate practices in recursive movement" (p. 54). According to this author, this requires that the training attends the different levels of students with specific developments for their age and context, as well as greater attention from professionals who think and organize the initial training, paying attention to basic education.

New ways of work emerge from the relationship between theory and practice. Certainly these should be studied, analyzed and discussed, enabling legitimacy with the technical and scientific discourse. However, the babies education, you cannot rule out certain developmental nature, since that there is accelerated progress on the physical aspects of the child, marked by subjectivity but mainly sociability promoters.

The idea of continued training in exercise, based on the occupational practice activities performed routinely, may favor a quality performance that respects and consider the particular needs of nursery children, as well as the characteristics of this level of education.

I think like this, in practice, like she does, being there with us. Nothing like being there and see how it works, because then she sees how it works, as it is, even in practice and, practice, teaching there and guiding us, I think it's cool, about everything she sees and that is out of standard that it believes it can improve ( $A D E, B B)$.

There is need for continued training organization, helping the occupational to improve their level of knowledge, but to provide the practice of it. We need this training happens during routine nursery, so that the practice can be incorporated slowly and within the possibilities.

\section{Final Considerations}

The research allows a deep knowledge about the daily life of the studied institutions, which is important to have a critical analysis of those institutions' reality to instigate further inquires and to help in public policies definition and training practices for this education stage.

It is found that the nursery occupationals still guide their practice to the care activities, looking to the nursery as an institution created to assist families who cannot afford to keep the child, either because the mother works outside, either by being exposed the social risks.

In this way, the educational procedures organized in the research methodology aimed to discuss this view in the proposal of routine activities and add knowledge that would allow a different view of practice. However, although the level of information of the participants modify the practices, almost nothing have changed, as they are not consolidated, having need to implement dedicated initial training specifically for this reality and continued supervision service, based on the practice of occupationals and the reality presented by the nurseries, in addition, of course, theoretical knowledge concerning this age group.

Also, the participation of all nursery team and the Municipal Education is essential for more substantial and permanent changes, in addition to structural changes, physical and material, in these institutions. 
It must be noted that the study was conducted in a medium-sized city of Sao Paulo, Brazil, portraying the conditions of many nurseries, but certainly far from reaching the totality of institutional and educational differences existing in the country. This has been the explanation for the promulgation of documents with general contents that bit help managers and professionals in nurseries in the definition of space and time, the activities, the pedagogical practice.

Besides that, there is need of more scientific research about nursery in order to discuss and analyze the various facets that make up this phase of education, contributing to the professionals who work on it. It is important for the municipal departments of education, the educational institutions that have nursery and the universities to engage in activities and contribute to the knowledge production in the area and with real solutions to the installed practices in order to provide increase quality in the care to little children.

A changing conception on aspects that compose the operation of early childhood education spaces, as well as restructuring, depends on and requires the participation of everyone who cares about an education that attend with quality to all children. Finally, the subject is interest of education, health and social areas, and the development of this research made possible theoretical and practical additions to these areas.

This work was financed by CNPq-Brazilian National Council of Scientific and Technological Development and UNESP.

\section{References}

Arce, A. (2010). O referencial curricular nacional para a educação infantil e o espontaneísmo [The National Curriculum Framework for Early Childhood Education and Spontaneity]. In A. Arce \& L. M. Martins (Eds.), Quem tem medo de ensinar na educação infantil?: em defesa do ato de ensinar [Who's Afraid of Teaching in Kindergarten?: In Defense of the Act of Teaching] (pp. 13-36). Campinas: Editora Alínea.

Bahia, C. C. S., Magalhães, C. M. C., \& Pontes, F. A. R. (2011). Mothers and Teachers’ Beliefs about the Development of the Child. Fractal: Revista de Psicologia, 23, 99-122.

Campos, M. M., Bhering, E. B., Esposito, Y., Gimenes, N., Valle, R., \& Unbehaum, S. (2011). The Contribution of Quality Early Childhood Education and Its Impacts on the Beginning of Fundamental Education. Educação e Pesquisa, 37, 15-33.

Campos, M. M., Esposito, Y. L., Bhering, E., Gimenes, N., \& Abucham, B. (2011). Early Childhood Education Quality: A Brazilian Study in Six Capitals. Cadernos de Pesquisa, 41, 20-54. http://dx.doi.org/10.1590/S0100-15742011000100003

Campos, M. M., Fullgraf, J., \& Wiggers, V. (2006). Brazilian Early Childhood Education Quality: Some Research Results. Cadernos de Pesquisa, 36, 87-128. http://dx.doi.org/10.1590/S0100-15742006000100005

Cerisara, A. B. (2002). The Brazilian Curricular Directives for Childhood Education in the Context of the Brazilian Educational Reform. Educação \& Sociedade, 23, 326-345. http://dx.doi.org/10.1590/S0101-73302002008000016

Correa, B. C. (2011). Early Childhood Education and Fundamental Education: Challenges and Mistakes in the Implementation of a New Policy. Educação e Pesquisa, 37, 105-120. http://dx.doi.org/10.1590/S1517-97022011000100007

DE Vitta, F. C. F. \& Emmel, M. L. G. (2004). The Duality between Care and Education in a Nursery Daily Activities. Paidéia (Ribeirão Preto), 14, 177-189.

Dias, R., Correia, J., \& Pereira, M. (2013). A creche e a construção da cidadania de mulheres e crianças em Portugal [The Nursery and the Construction of Citizenship of Women and Children in Portugal]. Revista de Educação Pública, 22, 665-687.

Dias, R., Pereira, F., \& Correia, J. A. (2014). Day Care, Gender Equality and the Right of Children to Education. Revista Portuguesa de Pedagogia (No Prelo).

Gatti, B. A. (2013). Education, School, and Teacher Education: Policies and Impasses. Educar em Revista, 50, 51-67. http://dx.doi.org/10.1590/S0104-40602013000400005

Kagan, S. L. (2011). Quality Matters in Brazil: Reviewing A Study-Recommending a System. Cadernos de Pesquisa, 41, 5667. http://dx.doi.org/10.1590/S0100-15742011000100004

Kramer, S. (2006). Children under 7 in Educational Policies in Brazil: Primary and Basic Education. Educação \& Sociedade, 27, 797-818.

Minayo, M. C. S. (2000). O desafio do conhecimento: pesquisa qualitativa em saúde [The Challenge of Knowledge: Qualitative Health Research] (7th ed.). São Paulo: Hucitec; Rio de Janeiro: Abrasco.

Neves, V. F. A. (2013). Collective History and Subjective Constructions: A Plot of Narratives in a Daycare Center Community. Educação em Revista, 29, 225-246. http://dx.doi.org/10.1590/S0102-46982013005000001

Nörnberg, M. (2013). From the Cradle to the Day Care: The Institution as "Home" and Place of Contact. Pro-Posições, 24, 99-113. http://dx.doi.org/10.1590/S0103-73072013000300007 
Oliveira, S. M. L. (2001). Crenças e valores dos profissionais de creche e a importância da formação continuada na construção de um papel junto à criança de 0 a 3 anos [Beliefs and Values of Childcare Professionals and the Importance of Continuing Education in the Construction of a Paper with the Child of 0 to 3 Years]. Em Aberto, 18, 89-97.

Oliveira, Z. M. R., Silva, A. P. S., Cardoso, F. M., \& Augusto, S. A. (2006). Construction of the Teaching Identity: Stories of Educators of Early Childhood Education. Cadernos de Pesquisa, 36, 547-571. http://dx.doi.org/10.1590/S0100-15742006000300003

Organização Para A Cooperação E O Desenvolvimento Econômico (2002). Starting Strong: Early Childhood, Education and Care. Brasília: UNESCO [OECD, 2001].

Paniagua, G., \& Palacios, J. (2005). Educação infantil: resposta educativa à diversidade [Early Childhood Education: Educational Response to Diversity]. Porto Alegre: Artmed Editora.

Pereira, F. (2009). Governo da infância e profissionalidade docente: Narrativas em formação inicial de professores [Childhood Government and Teaching Profession: Narratives in Initial Teacher Training]. Educação, Sociedade e Culturas, 29, 89-108.

Rosemberg, F. (2011). A criança pequena e o direito à creche no contexto dos debates sobre infância e relações raciais [The Small Child and the Right to Day Care in the Context of Debates about Childhood and Race Relations]. In M. A. B. Bento (Org.), Educação infantil, igualdade racial e diversidade: aspectos políticos, jurídicos, conceituais [Early Childhood Education, Racial Equality and Diversity: Political, Legal, Conceptual] (pp. 10-46). São Paulo: Centro de Estudos das Relações de Trabalho e Desigualdades-CEERT.

Santos, M. O. V. (2005). A identidade da profissional de educação infantil [The Identity of the Early Childhood Professional]. In C. M. Guimarães (Org.), Perspectivas para educação infantil [Prospects for Early Childhood Education] (pp. 87-101). Araraquara: Junqueira \& Marin.

Tardif, M. (2013). The Professionalization of Education Thirty Years Later: Two Steps Forward, Three Steps Back. Educação \& Sociedade, 34, 551-571. http://dx.doi.org/10.1590/S0101-73302013000200013

Vitta, F. C. F., \& Vitta, A. (2012). Promoção do desenvolvimento da criança no contexto educacional: o berçário [Promoting the Development of the Child in the Educational Context: The Nursery]. In L. O. Zaniolo, \& M. J. C. Dall’Acqua (Eds.), Inclusão escolar: Pesquisando políticas públicas, formação de professores e práticas pedagógicas [School Inclusion: Searching Public Policies, Teacher Training and Pedagogical Practices] (pp. 141-162). Jundiaí: Paco Editorial.

Vitta, F. C. F., Giroto, C. R. M., De Castro, R. M., Campanhã, D. A., De Souza, M. C. N., Solana, B. D., Novaes, C. F. M., Cicilino, J. E. M., \& Vitta, A. (2015). The Play in the Context of Early Childhood Education in the View of Nurseries Professionals. Creative Education, 6, 519-525. http://dx.doi.org/10.4236/ce.2015.65051

Volpato, C. F., \& Mello, S. A. (2005). Work and Education of Day Care Center Educators in Botucatu: Critical Reflections. Cadernos de Pesquisa, 35, 723-745. http://dx.doi.org/10.1590/S0100-15742005000300010

\section{Submit or recommend next manuscript to SCIRP and we will provide best service for you:}

Accepting pre-submission inquiries through Email, Facebook, LinkedIn, Twitter, etc.

A wide selection of journals (inclusive of 9 subjects, more than 200 journals)

Providing 24-hour high-quality service

User-friendly online submission system

Fair and swift peer-review system

Efficient typesetting and proofreading procedure

Display of the result of downloads and visits, as well as the number of cited articles

Maximum dissemination of your research work

Submit your manuscript at: http://papersubmission.scirp.org/ 